\title{
The effect of individual nutritional support and nurse follow-up on weight loss during radiotherapy in cancer patients
}

\author{
Serap Yücel ${ }^{1}$ iD , Sedenay 0skeroğlu Kaplan² ${ }^{\text {iD }}$, Zeynep Güral' ${ }^{1}$ (D) , Ayşin Kayışs \\ Fethullah Işık ${ }^{3}$ iD , Fulya Ağaoğlu' ${ }^{1}$ (D
}

${ }^{1}$ Acıbadem Atakent University

Hospital, Department of Radiation Oncology, Istanbul, Turkey

${ }^{2}$ Şanlıurfa Training and Research Hospital, Department of Radiation Oncology, Urfa, Turkey ${ }^{3}$ Acıbadem Atakent University Hospital, Department of Nursing, Istanbul, Turkey

Serap Yücel

Sedenay Oskeroğlu Kaplan

Zeynep Güral

Ayşin Kayı̧̧

Fethullah Işık

Fulya Ağaoğlu

\section{Correspondence:}

Serap Yücel

Acıbadem Atakent University Hospital, Department of Radiation Oncology, Istanbul, Turkey

Phone: +902124044076

E-mail: serapbaskaya@yahoo.com

Received : June 17, 2019

Revised : November 01,2019

Accepted : November 04,2019

\section{ABSTRACT}

Purpose: The aim of this study was to evaluate the nutritional status of patients receiving definitive or adjuvant radiotherapy with head and neck, pelvic, thoracic and intraabdominal tumors and to determine their weight loss.

Methods: 40 patients admitted to the radiation oncology outpatient clinic since 01.11 .2015 and planned; head, thoracic, abdominal and pelvic radiotherapy, were included in the study. The patients were evaluated before the treatment and in addition to the daily nutrition of the patients, special nutritional support was provided as $35 \mathrm{kcal} / \mathrm{kg}$ energy, $2 \mathrm{gr} / \mathrm{kg}$ protein and $15 \mathrm{mg}$ glutamine daily. The weight loss of the patients evaluated by radiation oncologists and nurses was recorded.

Results: The mean age was 61 years (range, 39-86 years). 9 patients with lung cancer were over 70 years old and had definitive radiotherapy. All patients underwent radiotherapy treatment without interrupting treatment, except for an 86-year-old patient scheduled for adjuvant therapy with gastric cancer and two patients with lung cancer receiving chemoradiotherapy. $72 \%$ of the patients continued their nutritional support during the entire treatment. When weight loss was evaluated, only $8 \%$ of patients had more than $10 \%$ weight loss. According to nutritional support, weight loss rates were found to be significantly lower in patients who fully applied for nutritional support ( $p: 0.003)$.

Conclusion: Early and intense nutritional support of cancer patients with risk of malnutrition may lead to less weight loss during radiotherapy.

Keywords: Radiotherapy, cancer, nutrition

KANSERLi HASTALARDA RADYOTERAPI SIRASINDA ÖZEL BESLENME DESTEĞi VE HEMŞIRE TAKIBi YAPILMASININ KILO KAYBI ÜZERINE ETKISI

ÖZET

Amaç: Çalışmanın amacı baş ve boyun kanserli, toraks, üst batın ve pelvis yerleşimli tümör tanısı ile definitif veya adjuvan radyoterapi almakta olan hastaların beslenme durumlarını değerlendirmek ve tedavi sırasında yapılan beslenme desteği ile kilo takiplerini tespit etmektir.

Yöntemler: Çalışmaya Radyasyon Onkolojisi polikliniğine 01.11.2015 tarihinden itibaren başvuran ve baş boyun, torakal, batın ve pelvik radyoterapi planlanan rastgele 40 hasta dahil edilmiştir. Hastalar tedavi öncesi değerlendirilmiş ve hastaların gündelik beslenmelerine ek olarak günlük $35 \mathrm{kcal} / \mathrm{kg}$ enerji, $2 \mathrm{gr} / \mathrm{kg}$ protein ve $15 \mathrm{mg}$ glutamin olarak özel beslenme destekleri sağlanmıştır. Poliklinik kontrollerinde radyasyon onkoloğu ve hemşiresi tarafından beraber değerlendirilen hastaların kilo kayıpları kaydedilmiştir.

Bulgular: Hastalarda ortalama yaş 61 (39-86 yaş) idi. 5'i akciğer kanseri olan 9 hasta 70 yaş üzerindedir ve definitif radyoterapi uygulanmıştır. Mide kanseri ile adjuvan tedavi planlanan 86 yaşındaki bir hasta ve akciğer kanseri ile kemoradyoterapi alan iki hasta dışında tüm hastalar tedaviye ara vermeden radyoterapi tedavisini almışlardır. Hastaların $\% 72$ 'i tüm tedavi boyunca beslenme desteklerine devam etmişlerdir. Kilo kaybı değerlendirildiğinde ise sadece $\% 8$ hastada $\% 10$ 'dan fazla kilo kaybı görülmüștür. Beslenme desteğine göre kilo kayıp oranları beslenme desteğini tam uygulayanlarda kilo kaybının anlamlı olarak daha az olduğu görülmüş̧ür ( $\mathrm{p}: 0.003)$.

Sonuç: Erken ve yoğun beslenme desteği uygulanarak malnütrisyon riski olan kanser hastalarında radyoterapi sırasında daha az kilo kaybı görülebilir.

Anahtar sözcükler: Radyoterapi, kanser, beslenme 
$\mathbf{N}$ utritional status in cancer patients significantly affects our treatment results. Progressive weight loss is a common feature of many cancers and the incidence of malnutrition in this patient group ranges between $40-80 \%$ (1-3). A recent review and observational studies show that diet and nutrient selection take a major role in cancer progression, recurrence risk, and overall survival. Also, $60-75 \%$ of patients with cancer had at least one additional disease, and the probability of death from non-cancerous causes was significantly higher than the normal population (4-7). Therefore, nutrition management is an important factor in the functional disorders, prevention and management of additional diseases. Cancer-related malnutrition arises as a result of the imbalance between the nutritional needs of the patient, tumor metabolism and the nutritional stores in the body (8-10). Prolonged nutritional deficiencies may result in clinical symptoms such as progressive, involuntary weight loss with cachexia, edema, impaired immune responses, reductions in motor and mental functions. Especially, treatment-related malnutrition observed more often in upper gastrointestinal system cancer patients treated with radiotherapy(RT)/chemoradiotherapy(RCT). Isenring et al. observed in their randomized study that patients treated with abdominopelvic radiotherapy and received early nutritional counseling had significantly better results in terms of weight loss, nutritional status and quality of life than patients who received standard information and a booklet about possible nutritional problems (11). Similarly, Ravasco et al. reported that nutrition counseling provided significant improvements in energy and protein intake with 111 colorectal cancer patients who received RT and better results were obtained in quality of life evaluations (12). The aim of this study is to identify weight loss in different types of cancer patients such as head and neck, thoracic, abdominal and pelvic cancers with the evaluation of their nutritional status and individual supportive therapy during radiotherapy treatment.

\section{Materials and methods}

Acibadem University Medical Research approval was obtained for this study. 'Information Form' and 'Radiation Oncology Patient Evaluation and Follow-up Form', in which the patients were evaluated and weight loss was recorded, were used. A total of 40 randomly assigned patients who were admitted to the Radiation Oncology outpatient clinic in November 2015 and who had a planned; head and neck, thoracic, abdominal and pelvic RT, were included in the study. The forms of the patients were evaluated before the RT and in addition to their basal nutrition, special nutritional supplements were given to include 35 $\mathrm{kcal} / \mathrm{kg}$ energy, $2 \mathrm{~g} / \mathrm{kg}$ protein and $15 \mathrm{mg}$ glutamine daily. Radiotherapy-related side effects and weight loss were recorded in patients evaluated at least once a week by a radiation oncologist and a nurse. 10 patients from each region were included in the study. IBM SPSS Statistics 22 (IBM SPSS, Turkey) was used for statistical analysis. The normal distribution of the parameters was evaluated by the Chi-square test and the numerical variables were analyzed using the nMann-Whitney $U$ test. Results were considered statistically significant with $p<0.05$.

\section{Results}

The mean age of the patients was 61 years (39-86 years) and 9 patients with lung cancer were older than 70 years. According to the diagnoses, patients with 1 Nasopharyngeal, 4 larynx/ Laryngeal, 5 oral cavity, 10 lung, 8 stomach, 2 pancreatic, 4 rectal, 4 endometrial and 2 cervical cancer received treatment. The diagnosis and treatment characteristics of patients are shown in Table 1. Except for an 86-year-old patient who was planned for adjuvant treatment with the diagnosis of gastric cancer and two patients who received CRT for lung cancer, all patients completed their treatment without interruption. $72 \%$ of the patients were able to adapt to the planned nutritional support. Weight loss of less than $5 \%$ was seen in $65 \%$ of patients and $8 \%$ of patients had a weight loss of more than $10 \%$. When weight loss rates according to nutritional support were evaluated, weight loss was found to be significantly less in those who fully applied nutritional support ( $\mathrm{p}: 0.003$, Table 2). However, there was no statistically significant relationship between primary cancer diagnosis and weight loss.

\begin{tabular}{|c|c|c|c|c|}
\hline $\begin{array}{l}\text { Type of } \\
\text { cancer }\end{array}$ & $\begin{array}{l}\text { Number of } \\
\text { Patients ( } n \text { ) }\end{array}$ & Age & $R T$ & $\begin{array}{c}\text { Nutritional Support } \\
\text { Full-Received } \\
\text { Patient (n) }\end{array}$ \\
\hline $\begin{array}{l}\text { Head and Neck } \\
\text { Nasopharynx } \\
\text { Larynx } \\
\text { Oral Cavity }\end{array}$ & $\begin{array}{l}1 \\
4 \\
5\end{array}$ & $\begin{array}{c}39 \\
48-84 \\
47-64\end{array}$ & $\begin{array}{l}\text { Definitive } \\
\text { Adjuvant } \\
\text { Def+Adj }\end{array}$ & $\begin{array}{c}70 \%(7) \\
100 \%(1) \\
100 \%(4) \\
40 \%(2)\end{array}$ \\
\hline $\begin{array}{l}\text { Thorax } \\
\text { NSCLC* } \\
\text { SCLC** }\end{array}$ & $\begin{array}{l}7 \\
3\end{array}$ & $\begin{array}{l}61-78 \\
52-84\end{array}$ & $\begin{array}{l}\text { Definitive } \\
\text { Definitive }\end{array}$ & $\begin{array}{l}60 \%(6) \\
71 \%(5) \\
66 \%(1)\end{array}$ \\
\hline $\begin{array}{l}\text { Upper Abdomen } \\
\text { Stomach } \\
\text { Pancreas }\end{array}$ & $\begin{array}{l}8 \\
2\end{array}$ & $\begin{array}{l}39-86 \\
66-81\end{array}$ & $\begin{array}{l}\text { Adjuvant } \\
\text { Adjuvant }\end{array}$ & $\begin{array}{c}\% 90(9) \\
\% 88(7) \\
\% 100(2)\end{array}$ \\
\hline $\begin{array}{l}\text { Pelvic } \\
\text { Rectum } \\
\text { Endometrium } \\
\text { Cervix }\end{array}$ & $\begin{array}{l}4 \\
4 \\
2\end{array}$ & $\begin{array}{l}44-82 \\
46-69 \\
54-66\end{array}$ & $\begin{array}{c}\text { Preoperative } \\
\text { Adjuvant } \\
\text { Definitive }\end{array}$ & $\begin{array}{l}70 \%(7) \\
75 \%(3) \\
75 \%(3) \\
50 \%(1)\end{array}$ \\
\hline
\end{tabular}


Table 2. Weight loss rates according to nutritional support

Nutrition Support (Number of Patients)

\section{Weight Loss}

Percentage

$<5 \%$

Full-applied

Poor applied

Total

$5-10 \%$

24

2

26

$>10 \%$

3

2

Total

29

P: 0.003

\section{Discussion}

According to the results of the study, individual diet counseling provided during the treatment positively affects the weight control of cancer patients. The fact that weight loss is significantly lower in patients with complete nutritional supplementation and additional energy and protein intake is an important need in cancer patients. Although there was no significant relationship between the diagnosis of primary cancer and weight loss, primary tumor localization and stage can make a difference at long term follow-up after RT.

A proper diet can contribute to the management of weight loss in cancer, which is caused by side effects (reduced intake of food, nausea, vomiting, constipation, diarrhea, malabsorption, stomatitis and taste changes) associated with treatments such as chemotherapy (CT) and radiation therapy (RT) (11-15). However, in spite of the intensive care provided during RT, patients may not be able to adapt to the planned nutritional support, because patients may need professional help against psychological changes such as anxiety, depression, hopelessness and feelings of isolation. Therefore, short and long-term follow-up of patients to continue to receive both physiological and psychological support against possible changes in nutritional gains and disease can contribute to the prognosis in a positive way.

In a review of 11 controlled randomized studies published by Stratton and Elia in 1999, it was concluded that oral nutritional supplements did not benefit in terms of weight and body composition in cancer patients (16). Several studies have found that, despite the increase in protein and energy intake, it only slows down the rate of weight loss in patients receiving $\mathrm{CT}(17,18)$. In a Cochrane review, which investigated the effect of dietary counseling in malnourished patients receiving and not receiving oral dietary supplements in 2004, it was concluded that nutritional supplements were more important than dietary counseling in maintaining body weight, even if there was insufficient evidence to reduce morbidity and mortality (19).

Nutritional support has been shown to improve overall survival, weight gain, or functional outcomes in cancer patients $(2,16)$. Nevertheless, an important limitation of these studies was the lack of adequate definition of nutritional counseling such as control frequency, follow-up. In a study published in 2002 by Capra et al., it is emphasized that the lack of adequate nutrition programs and adherence of these studies to patient-oriented issues such as quality of life and patient satisfaction may be responsible for the negative consequences of diet studies (20). In a randomized controlled study by Isenring et al. in 2004, radiation oncology protocols and nutritional counseling, appropriate to medical nutritional therapy generated by the American Dietetic Association and Morrison Health Service to improve patient outcomes and reduce health care costs, compared to standard practices (general nutrition speech and booklet) have shown a positive effect on body weight, nutritional status and quality of life (11). In 2007, the same study group similarly demonstrated that nutritional intervention in patients receiving radiotherapy to the gastrointestinal or head and neck region provided better dietary intake (protein, energy, fiber) in addition (22). In our current study, it can be said that the reason /for superiority obtained in terms of maintaining body weight is the density and frequency of nutritional counseling as well as nutritional supplements. Especially minimization of eating difficulties experienced by patients receiving RT to the gastrointestinal tract and head and neck region is very important in terms of weight control.

In cancer patients, the solution /to the problems related to nutrition requires a holistic approach, continuous intervention, evaluation and counseling. If intensive and personalized nutrition programs with continuous nursing support can be implemented, better weight control during RT can be achieved. When considering the possible effects of weight loss on disease prognosis and completion of treatments, it would be more appropriate to treat each patient with these evaluations and supports before and during RT. 


\section{References}

1. Laviano A, Meguid MM., Nutritional issues in cancer management. Nutrition. 1996; 12: 358-71. [CrossRef]

2. Bozzetti F. Nutrition support in patients with cancer. In: Payne-James J, Grimble G, Silk D, editors. Artificial Nutrition Support in Clinical Practice. 2nd ed. London; 2001;639-80.

3. Bozzetti F, Mariani L, Lo Vullo S, Group SW, Amerio ML, Biffi R, et al: The nutritional risk in oncology: a study of 1,453 cancer outpatients. Support Care Cancer 2012;20:1919-28. [CrossRef]

4. Dewey A, Baughan C, Dean TP, Higgins B, Johnson I. Eicosapentaenoicacid (EPA, an omega-3 fatty acid from fish oils) for the treatment of cancer cachexia. Cochrane Database Syst Rev. 2007; CD004597. [CrossRef]

5. Correia MI, Waitzberg DL. The impact of malnutrition on morbidity, mortality, length of hospital stay and costs evaluated through a multivariate model analysis. Clin Nutr. 2003; 22: 235-9. [CrossRef]

6. Naber TH, Schermer T, de Bree A, Nusteling K, Eggink L, Kruimel JW, et al. Prevalence of malnutrition in nonsurgical hospitalized patients and its association with disease complications. Am J Clin Nutr. 1997;66: 1232-9. [CrossRef]

7. Schattner M, Shike M. Nutrition support of the patient with cancer. In: Shils ME, et al., editors. Modern nutrition in health and disease. 10th ed. Philadelphia: Lippincott Williams \& Wilkins; 2005. p. 1290-313.

8. Fearon K, Strasser F, Anker SD, Bosaeus I, Bruera E, Fainsinger RL, et al. Definition and classification of cancer cachexia: an international consensus. Lancet Oncol. 2011;12: 489-95. [CrossRef]

9. Baracos VE, Martin L, Korc M, Guttridge DC, Fearon KCH. Cancerassociated cachexia. Nat Rev Dis Prim. 2018;4: 17105. [CrossRef]

10. DeVan Der Schueren MAE, et al. Systematic review and meta- analysis of the evidence for oral nutritional intervention on nutritional and clinical outcomes during chemo(radio)therapy: current evidence and guidance for design of future trials. Ann Oncol. 2018;29:114153. [CrossRef]

11. Isenring EA, Capra S, Bauer JD. Nutrition intervention is beneficial in oncology outpatients receiving radiotherapy to the gastrointestinal or head and neck area. Br J Cancer. 2004;91:447-52. [CrossRef]

12. Ravasco P, Monteiro-Grillo I, Vidal PM, Camilo ME. Dietary counseling improves patient outcomes: a prospective, randomised, controlled trial in colorectal cancer patients undergoing radiotherapy. J Clin Oncol. 2005;23:1431-8. [CrossRef]
13. Paccagnella A, Morello M, Da Mosto MC, Baruffi C, Marcon ML, Gava $A$, et al. Early nutritional intervention improves treatment tolerance and outcomes in head and neck cancer patients undergoing concurrent chemoradiotherapy. Support Care Cancer; 2010:18;83745. [CrossRef]

14. Isenring $E$, Capra $S$, Bauer J. Patient satisfaction is rated higher by radiation oncology outpatients receiving nutrition intervention compared with usual care. J Hum Nutr Diet. 2004; 17:145-52. [CrossRef]

15. Langius JA, Bakker S, Rietveld DH, Kruizenga HM, Langendijk JA, Weijs PJ, et al. Critical weight loss is a major prognostic indicator for disease-specific survival in patients with head and neck cancer receiving radiotherapy. Br J Cancer. 2013; 109: 1093-9. [CrossRef]

16. Stratton R, Elia M. A critical, systematic analysis of the use of oral nutrition supplements in the community. Clin Nutr. 1999; 18: 29-84.

17. Evans WK, Nixon DW, Daly JM, Ellenberg SS, Gardner L, Wolfe E, et al. A randomized study of oral nutritional support versus ad lib nutritional intake during chemotherapy for advanced colorectal and non-small-cell lung cancer. J Clin Oncol. 1987; 5: 113-24. [CrossRef]

18. Ovesen L, Allingstrup L, Hannibal J, Mortensen EL, Hansen OP. Effect of dietary counseling on food intake, body weight, response rate, survival, and quality of life in cancer patients undergoing chemotherapy: a prospective, randomized study. J Clin Oncol. 1993;11: 2043-9. [CrossRef]

19. Baldwin C, Parsons T, Logan S. Dietary advice for illness-related malnutrition in adults. In: The Cochrane Library issue 2. Oxford; 2004. Update Software.

20. Capra S, Bauer J, Davidson W, Ash S. Nutritional therapy for cancerinduced weight loss. Nutr Clin Pract. 2002; 17: 210-3. [CrossRef]

21. The American Dietetic Association and Morrison Health Care. Medical Nutrition Therapy Across the Continuum of Care. 2nd ed. Chicago, IL: American Dietetic Association; 1998.

22. Isenring EA, Bauer JD, Capra S. Nutrition Support Using the American Dietetic Association Medical Nutrition Therapy Protocol for Radiation Oncology Patients Improves Dietary Intake Compared with Standard Practice. J Am Diet Assoc. 2007; 107:404-12. [CrossRef] 